
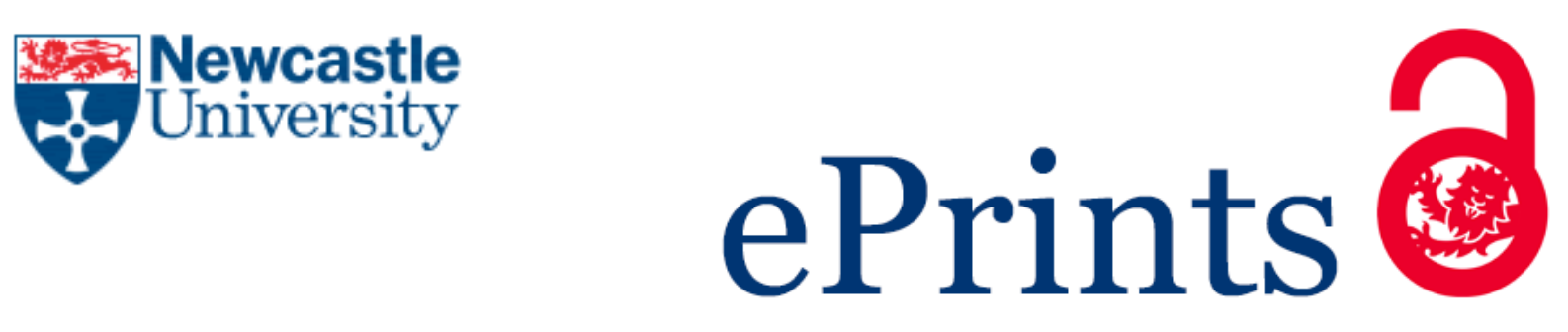

\title{
Baldoli C.
}

'With Rome and with Moscow': Italian Catholic Communism and Anti-Fascist Exile.

Contemporary European History 2016, 25(4), 619-643.

\section{Copyright:}

This article has been published in a revised form in Contemporary European History, http://dx.doi.org/10.1017/S0960777316000448. This version is free to view and download for private research and study only. Not for re-distribution, re-sale or use in derivative works. (C) Cambridge University Press, 2016.

Date deposited:

$01 / 11 / 2016$ 


\section{'With Rome and with Moscow': Italian Catholic Communism and Anti-Fascist Exile $^{1}$}

This article aims to explore the interplay between religion and political radicalism in Europe by focusing on the case of Italian White Leagues (Catholic peasant unions) in the interwar period. Interest in this movement stems partly from the opinion that the understanding of politics in early twentieth-century Europe has often been distorted by historiographical focus on the political polarisation between communism and fascism, which has led to the neglect of the complex ideological area in between. While there are a great many studies on Comintern and on European fascism, little scholarly work exists on so-called 'Catholic communism'. Although marginal in Britain and in protestant Europe (where some interesting attempts to reconcile Christianity and Marxism can nevertheless also be found), it was present in Catholic countries, and in Italy in particular. $^{2}$

The first instances of Catholic interest in the social question in Italy emerged as a response to socialist organisation among the working classes in the late nineteenthcentury. Socialist Leagues were founded among the peasantry in the early 1880 s, a Socialist Trade Union (Camera del Lavoro) in 1883 and the Italian Socialist Party in 1892. A wave of strikes at the beginning of the twentieth century imposed labour contracts on the landowners of the Po Valley for the first time. Recognising that socialism sought to improve the conditions of life for the peasantry but worried about its anti-clericalism, the bishop of Cremona, Geremia Bonomelli, published a pastoral letter in 1886 that urged Catholics to take part in works of social assistance to the poor; this was followed, in 1891, by Pope Leo XIII's encyclical Rerum Novarum, which encouraged Catholics to come to terms with the modern age. Around the same time 
Romolo Murri created a Christian Democratic movement, anticipating the foundation in 1918 of a Catholic trade union, the Italian Workers' Federation (Confederazione Italiana dei Lavoratori), and of a Catholic political party, Luigi Sturzo's Italian Popular Party (Partito Popolare Italiano; PPI) a year later. ${ }^{3}$

On the extreme left of this emerging Catholic social movement were the White Leagues, which were established after 1904. They were variously described in their own newspaper Action (L'Azione) - founded by their leader Guido Miglioli the same year, and later destroyed by the fascists in 1922 - as 'Christian social' unions, a Catholic workers' movement or 'proletarian Catholic' leagues. This revolutionary minority turned May Day into a celebration for Catholic land labourers as well as industrial workers, and as a result was accused by the Church hierarchy of having turned to socialism. Following the Bolshevik revolution in 1917 and the foundation of the Italian Communist Party in 1921, the landowners' and later the fascist press described the movement as 'white Bolshevik' and 'communist'. Although they never accepted such definitions, its leaders addressed the perennial longing of the peasant masses for emancipation by emphasising the socialist message that they believed lay at the heart of Christianity. Some of them were persecuted by the fascists and fled Italy after Mussolini's seizure of power.

After the fall of the Berlin Wall and the 'death of ideologies', historians have devoted more attention to the role of religion, both in the treatment of individual biography and in the study of political movements. ${ }^{4}$ This article is a contribution to that 'rediscovery' of religion in twentieth-century historical discourse, concentrating on the case of Italian Catholic anti-fascist exiles and their transnational networks and activities. According to classical geo-political definitions, borders circumscribe a portion of territory and the limits of the sovereignty exercised over it. The aspiration towards an alignment between state, population and territory has strongly influenced European and 
extra-European history during the last two centuries, characterised by political and military conflicts whose origins can be traced back to the attempt to define or redefine the space occupied by states. ${ }^{5}$ However, border cities and regions are also spaces of resistance, where dynamics of discontent can emerge, and they certainly played an important role in interwar Europe for anti-fascist exiles whose lives were for a number of years characterised by the need to cross and re-cross borders. The itineraries of these groups intersected in terms of place, joint campaigning, activist milieus and responses to events such as the accession of Hitler in 1933, the Spanish civil war or the Soviet show trials. Charting these developments helps us to understand the evolution of the ideas of the European left during this period in ways that national histories are not capable of capturing.

This article aims to show how conventional historical writing on political ideas and campaigns focused only on sovereign national states robs us of the critical transnational element in anti-fascist exile politics - a dimension that is central in understanding how religious and political discourses are constructed. ${ }^{6}$ It does so by focusing on Guido Miglioli, the main organizer of the White Leagues in Italy, and on the development of his thought, activities and networks as he found refuge in France, Germany and Belgium during the years of Mussolini's dictatorship. Born in the province of Cremona, where he became a Catholic deputy in 1913 (six years before an Italian Catholic party was founded), his opposition to the First World War, to landowners and to fascism forced him into a long period of exile to avoid persecution in the mid-1920s. Together with other exiles he developed a network of political contacts across Europe with the aim of resuscitating the anti-fascist struggle in Italy and of launching a campaign for the liberation of the peasantry from economic exploitation. This was to be achieved through a European Peasant International that would draw from the Soviet example while maintaining its Christian roots. 
White Leagues: The Italian Context

Supporters of various forms of religious socialism contributed to building bridges between apparently opposing worldviews, while at the same time initiating conflicts within their own field of activity and belief. This was the case of the left-wing tradition in Italian Catholicism, the origins of which can be found in the development of Christian peasant trade unionism in the first half of the twentieth century. From the late nineteenth century, not only was left-wing Catholicism not exempt from socialist ideas, but socialism in the northern Italian plains was similarly open to evangelical influence. It was here that the battles for labour contracts up to the First World War and the strikes of the post-war period led the landowners to resort to the use of fascist violence, instilling in the peasantry profound feelings of revenge. At the centre of these struggles were both the socialist ('Red') and the Catholic ('White') Leagues. The latter sought reconciliation between the religious rituals and traditions of the Italian peasantry and a political culture directly imported from socialism. The climax of this marriage was reached in 1921, when in the Po Valley, centred on the province of Cremona, 'White' peasants occupied farms and declared self-government. ${ }^{7}$ As Antonio Gramsci later noted while imprisoned by the fascists, these methods were more radical than the ones employed by socialism, and were indeed remembered during Mussolini's regime as forms of 'White Bolshevism'. 8

The newspaper of the White Leagues - L'Azione - tried to maintain the difficult balance between Catholic hierarchies and peasant activism. By 1914 the newspaper had expanded among Catholics beyond Cremona, becoming the voice of a larger group and attracting activists from all over the Po Valley. It was the genuine 
expression of a peasant movement, which aspired to a revolution 'against the background of an evangelical landscape'. The Gospel was 'interpreted as a sublime Labour Charter'. ${ }^{9}$

The Cremona countryside was also the birthplace and political arena for the founder of the Italian Socialist Party, Leonida Bissolati, who met the peasant masses coming out of the churches in their villages, with the gospel in his hand, telling them: 'you have listened to the minister of God; now do listen to the minister of the poor' ${ }^{10}$ The Marxist content of his speeches was explained using allegories and parables from the Gospel. The same phenomenon occurred throughout the Po Valley, where socialist leaders explained to the masses how to fight in order to construct the 'socialist Paradise' in this world. ${ }^{11}$ The belief that the Christian and the socialist message were at heart very similar could generate conversions between the two camps. Bissolati's father had been a priest and then became a socialist. In the province of Cremona, the Christian spirit that permeated the speeches of some well-known socialist leaders proved powerful enough to prompt conversions to the priesthood. ${ }^{12}$ Some of Miglioli's collaborators who started training as priests abandoned the seminary to become White League organisers. One of them, Romano Cocchi, fled into exile in 1926 and in 1937 founded the most popular Italian communist organisation in France, the Union Populaire Italienne. ${ }^{13}$ Before leaving Italy, he wrote a number of pamphlets that were critical of the institutional Church and reminded the peasants that it had betrayed the original Christian message. 'St Paul and Lenin', he argued, 'sustain together: those who do not work do not eat'. He cited French politician and mutualist philosopher Pierre-Joseph Proudhon, whose notion that property was theft concurred with views already expressed by Catholic saints, such as St Basil, St Hieronymus and St Clemens. He also drew on the New Testament and in particular the Gospels to attack the privileges of the rich, quoting Jesus, St Luke and St 
Matthew. The Acts of the Apostles, in his view, showed perfectly how communism was practised among ancient Christian communities. ${ }^{14}$

Although they are not the focus of this article, it is important to recall that there were also Catholic anti-fascist exiles who were anti-communists, like the founder of the PPI Luigi Sturzo. Despite outstanding success in both the 1919 and 1921 parliamentary elections, in which it earned 100 and 108 seats respectively, the first Catholic political party in Italy was by 1924 riven by internal divisions - in particular between anti-fascists, led by Sturzo, and conservatives, who favoured an alliance with Mussolini - and won only 39 seats at the national elections that year. The PPI was eventually suppressed by Mussolini, with Pope Pius XI's consent, in 1926. The most prominent followers of Sturzo were Giuseppe Donati and Francesco Luigi Ferrari, both of whom died during the exile, in 1931 and 1933 respectively. Unlike Miglioli, they all rejected the concept of class struggle and a class-based interpretation of Christianity and sought to recreate the PPI abroad, with little success. ${ }^{15}$ Deep divisions on the left of the party had been revealed in 1924 in two decisive interviews in the Italian press. In February, in the Turinese newspaper La Stampa, Sturzo expressed the opinion that, from a political, philosophical and religious point of view the gap between the fascist conception of the state and Christian principles was unbridgeable. ${ }^{16}$ In this way he made a clear break from clerical fascists, who were to bear responsibility for their acceptance of the regime, but he did not propose any alliance with non-Catholic anti-fascist parties. Instead that was a solution advanced by Miglioli in an interview given to the communist newspaper Unity (L'Unità) in December, which provoked his expulsion from the PPI in January 1925. In this interview, Miglioli called for unity between the Catholic and the socialist trade unions and for putting clerical-anticlerical divisions to one side. ${ }^{17}$

During the years of exile, both Sturzo and Miglioli failed to create a 'White International' that would represent Catholic trade unionism - from Sturzo's point of 
view, a rival of the third International; in Miglioli's judgement, an alliance with it. On the one hand, following two international meetings of Christian trade unions at Cologne in 1928 and at Utrecht in 1931, both attended by Ferrari, the founders were met by Vatican indifference, which hindered the success of the organisation. ${ }^{18}$ On the other, Miglioli was too close to Comintern to be able to unify European Catholic trade unionism. However, as the title of his 1945 memoir suggested, he spent those years attempting to build a bridge between the city that symbolised his religious faith (Rome) and the one that represented his political dream (Moscow). ${ }^{19}$

\section{A Life Across Borders: Italian Anti-Fascist Exiles in the Interwar Period}

Italian exiles moved from country to country during the 1920s and 1930s. Their national identities and concept of nation in relation to their anti-fascism was influenced by the experience of exile. As with other anti-fascists throughout the world, they constructed their own ideal homeland, a land of truth and intellectual honesty outside their own countries. $^{20}$

In the case of Miglioli, the concept of fatherland defied conventional borders, being concomitantly both local and transnational. His first homeland was the Po valley countryside where he grew up - the child of a landowner and of a devout Christian mother - and where he became famous as the 'white Bolshevik'. He graduated in law at the University of Parma and had the chance to pursue a brilliant career. Instead, he devoted his life to the struggle of the peasantry, spent part of his life in exile and lived and died in poverty, only supported by help from his family and small earnings from his publications. His ideal homelands were Rome, at the centre of Catholic civilisation, and the Soviet Union, the first country where, he later argued in a number of interwar publications, a revolution had realised in this world a society based 
on the Christian principles of equality and justice. ${ }^{21}$ It proved more difficult to settle in any one country during his exile. He travelled through a number of European countries, including Russia, Yugoslavia, England, Spain, and Eastern Europe, but primarily France, Belgium and Germany, always in precarious conditions, sometimes unable to renew his passport and permits to stay, usually at the mercy of local political developments. During his wandering around Europe he met both Italian and foreign socialists, communists and Catholics, anti-fascists from Italy and from other parts of Europe, many of whom lived the same uncertain life across borders within a continent increasingly controlled by authoritarian regimes and endangered by the threat of a new war. Among his many activities in exile was his involvement in the Peasant International, the International Red Aid, the European Peasant Committee, the League for the Rights of Man and the Anti-Colonial Movement.

His first border crossing was the flight from dictatorship in Italy. Following his ban from Cremona, as well as a number of physical attacks and the devastation of his own home, he escaped through Switzerland, assisted by Catholic priests on both sides of the border. At a trial for his illegal escape in July 1927 at the Court of Justice at Sondrio, Miglioli was condemned to four years of prison and a 20,000 lire fine, and the priests who helped him were given two-and-a-half years imprisonment and a 16,000 lire fine. While the priests were sent to prison, the forty-seven year old Miglioli journeyed between Lugano, a number of German cities and Moscow, until he eventually settled in Paris in September $1927 .^{22}$

Between 1922 and 1926 fascist laws imposed a choice between exile and clandestine life. Those who chose the latter did so in the hope that they could continue their commitment to oppose fascism by other means. The decision to carry on was 'the last possible political act' against the propaganda of regime which the Paris-based, socialist-dominated Anti-Fascist Concentration (Concentrazione antifascista), later 
defined as an army of occupation, responsible for hauling Italy back into the Middle Ages. ${ }^{23}$ Writing from Germany to his 'vanished friends' in 1937, the anti-Nazi activist Friedrich Reck underlined the frustration of those who decided to stay: 'do you, who left Germany four and more years ago, have any idea of how completely without legal status we are, of what it is to be threatened with denunciation at any time by the next hysteric who comes along? ${ }^{24}$ In fact, although they fled with the hope of acting politically from abroad, the exiles found themselves in conditions that were not very different from that of those taking part in clandestine activity in their own countries. They had to survive in precarious conditions and find new resources. They needed permits to travel and to stay and work, and, when those were not granted, they were forced to live a clandestine existence. They missed their hometowns, friends and families, had to learn new languages, and lived in anxiety about the future. ${ }^{25}$ They were subject to police searches of their homes, continuous surveillance of their movements and the confiscation of their correspondence. The material danger was less than in Italy or Germany, where their lives would have been at risk, but even this immunity was not always certain.

In 1937 the renowned anti-fascist brothers, Carlo and Nello Rosselli, were murdered in France; the situation only worsened after the German victory in 1940, placing many in France and in other occupied countries at risk of deportation to Nazi camps. ${ }^{26}$ The activities of anti-fascists were continuously infiltrated by spies, organised both from Italy by the Organization for the Vigilance and Repression of Anti-Fascism (Organizzazione per la Vigilanza e la Repressione dell'Antifascismo; OVRA), established in 1927 and locally by both the Italian 'Fascists Abroad' and the diplomatic authorities. $^{27}$

In the 1930s anti-fascist exiles' illusions were continually shattered by events. Between 1935 and 1936 they hoped that the war in Ethiopia might be a major 
miscalculation for the regime and provoke its collapse; however, they were forced to accept that Mussolini's victory made their chances of returning to Italy even more remote. The experience of exile at times led anti-fascist groups to overcome ideological differences and unite in common struggle; however, the real shift came when the Spanish and the French left won national elections in February and May 1936 respectively, providing a concrete demonstration of unity to European anti-fascist factions. ${ }^{28}$ The Spanish Civil War in particular influenced the evolution of a temporary alliance between anti-fascist parties in exile and was crucial in defining new agreements made between socialists, communists and republicans as a prelude to the Italian resistance in the Second World War. ${ }^{29}$ Yet shortly afterwards, in 1937, Stalin began the purges in Russia, which wrecked, in the eyes of many communists and fellow-travellers, the Soviet myth.

These various sites of exile and the problems they posed to those who sought safety therein provide the historian with an ideologically complex history of Europe. For instance, the biographical file compiled by the fascist police on the Catholic communist Romano Cocchi represents a typical example of life in the anti-fascist diasporas during the interwar years. Born in the province of Bologna, Cocchi began training to become a priest, but in 1915 at the age of twenty-two abandoned the idea. He moved to the Cremona countryside to follow Miglioli, becoming his political secretary; in 1925 he was in Milan; in 1926, condemned to internal exile (confino), he fled to Yugoslavia and from there to Vienna and Paris. In 1928 he was expelled from France for his communist activity but returned there as a clandestine a year later, under a false name. From there, he often travelled to Switzerland, Belgium and Germany. In 1930 he was in Basel; in 1931 again in Paris; in 1933 he was arrested at Lugano, then moved to Zürich but was expelled from Switzerland because of his communist propaganda. After that his presence was noted in Metz and again in Paris, where he was particularly 
involved in 1935-36 in protests against Italy's invasion of Ethiopia. In 1937 he moved between Vienna and Paris; in Nancy he became general secretary of the Union Populaire Italienne and director of its anti-fascist daily newspaper The Voice of the Italians (La Voce degli italiani). ${ }^{30}$ In 1940 he was arrested by the Gestapo and in 1944 he died at Buchenwald. Unlike Miglioli, who followed a similarly erratic path (although he managed to return to Italy, where he was arrested and in 1941 sent to confino), Cocchi abandoned the Catholic Church and embraced communism entirely until he broke with Moscow over the crisis provoked by the 1939 Nazi-Soviet pact. As Cocchi's case shows border crossing in the interwar period was indeed both geographical and ideological, something the relationship between Catholicism and communism demonstrates.

Guido Miglioli's Journeys to Moscow

One of the main poles of attraction for communist exiles was the Soviet Union. Although he did not define himself as a communist, in 1925 Miglioli spent six months there in order to study the condition of the peasantry and Soviet land reforms. He returned briefly to Italy and then fled to Paris where he published a number of books on the subject, declaring Russia to be his second fatherland. His invitation to Moscow by Comintern was prompted at the suggestion of the leaders of the Italian Communist Party (until 1943 Partito Comunista d'Italia; PCd'I) following the above-mentioned interview that Miglioli released to L'Unità in December 1924 and a discussion between Miglioli, Gramsci and the two main leaders of the peasantry in the PCd'I, Giuseppe Di Vittorio and Ruggero Grieco. Following his first visit to the Soviet Union his book One History and One Idea was published in Italy in 1926 after encouragement by anti-fascist activist and journalist Piero Gobetti (who was shortly afterwards to die in France after being 
assaulted by fascists in Turin). ${ }^{31}$ Miglioli’s Christian vision of Bolshevism stemmed from his observations of the Po Valley countryside, where the peasantry had been subject to centuries-long religious education, and where the Catholic and socialist unions had threatened the conservative stance of the Church. In his next book on the subject, published in France a year later and widely publicised by anti-fascist author Romain Rolland, Miglioli argued that, although the Soviet Union served as an example, both during and after the First World War the White Leagues in Italy had voiced the slogan 'land to the peasants', realising that such an aspiration could only be obtained through revolution. ${ }^{32}$ The Leagues' organisers, just like the leaders of the rival socialist trade unions, believed that a policy which did not accept the concept of class struggle would not be effective because no collaboration or solidarity with the peasantry could be expected from the landowners. ${ }^{33}$ In an open letter to Italian Catholic peasants in 1925, Cocchi reminded them that the Russian Revolution had been successful because rural and industrial workers had united: "now they have power themselves and are able to regulate their own economic conditions', ${ }^{34}$

To Miglioli, the condition of the Russian peasants during the Revolution appeared similar to the Italian situation. It was characterised by an inextricable link between socialism and religion. The Menshevik and Bolshevik leaders, just like leftwing Catholics in the Po Valley, were welcomed by the masses as apostles and bearers of a message of social justice and brotherhood. ${ }^{35}$ According to Miglioli this was particularly the case in Lenin's relationship with the peasants, a 'natural bond' that was evident in the way they gazed at Lenin's image 'with an elevated feeling of devotion and love'. These peasants, he believed, were 'extraordinarily religious' for 'they adore God who had created him; they love the man who had redeemed Him' ${ }^{36}$

The image of a world with no more landowners was now a historical fact, no longer a myth and, with its assurance of redemption, carried a promise to all, whether 
Catholic or not. The two palingenetic events, the resurrection of Christ and the Russian revolution, were now intertwined: the second was strengthened by the existence of the first; the past traditions were now presented with a new future. ${ }^{37}$ As Arthur Koestler, the Hungarian communist writer exiled in France, who after 1939 would become an ardent anti-communist, reflected in his autobiography, Christianity, like socialism, could only provide 'theoretical blueprints of the future', whilst the Soviet utopia 'was already incarnated in a real country with real people'. ${ }^{38}$ However, for Miglioli Christianity remained superior because it combined the spiritual realm with the promise of social revolution. Although he believed the communist and the Christian utopias to be ideologically compatible, he was never a Marxist because of Marx's claim about religion that 'in the brightness of day the lamp would become superfluous' ${ }^{39}$

Miglioli's importance at this point lay in his understanding that it was necessary to build a bridge between the Catholic peasant masses (whether socialist or not) and the socialist (and later communist) factory workers. Leaving the religious question aside, this was not far from the content of Gramsci's 'Theses of Lyon'. At the crucial meeting in 1926 that brought the PCd'I in line with the Third Communist International set up by Lenin in 1919, Gramsci defined Miglioli as the representative of the peasant left in the Popular Party. This left-wing faction had become critically important in the strategy of the now clandestine Communist Party. Influenced by the constitution of the Peasant International, which called on the unity of all potential anticapitalist forces, including the poor peasants, the PCd'I no longer regarded the peasantry as the reserve army of the reactionaries. ${ }^{40}$

The Soviet Union was also praised by Miglioli (an intransigent pacifist in 1914-1918) as the country that had rejected war. In his 1945 memoir he declared: 'hatred of war is Christian; love for the poor is Christian; passion for knowledge is Christian; all this helps to project the meaning of life into the afterlife; it provokes the 
need to became closer to He, who said about himself: "I am spirit and life"., ${ }^{41}$ Miglioli used these words in speeches addressed to meetings in the Soviet Union, where his audience asked him why he was a Christian rather than a communist if he was so willing to praise the Soviet revolution. He replied that Christianity brought communism beyond the limits of earthly life. ${ }^{42}$ As he spelled out in his preface to Le Village soviétique, 'I am neither communist, nor socialist. I have been educated within the social Christian school' ${ }^{43}$ He still maintained these views when, following further journeys to the Soviet Union, he wrote a book on collectivisation, published with the support of the International Agrarian Institute (a section of the Third International) in 1934. Here, too, he explained that the choice he had made to spend his life fighting for the rights of the humble and the oppressed among the workers of the land was a result of his Christian education. Peasant subjugation was perpetrated in a particularly cruel form by fascism, as he knew from his Italian experience; however, it was something present in all the capitalist countries that he had so far had the opportunity to visit. ${ }^{44}$ After the Soviet Revolution, a decree of 26 October 1917 authorised the expropriation of land, to be given by the State to those who worked it. This, according to Miglioli, was an 'evangelical document' ${ }^{45}$ When he came to describe what Russian revolutionaries told the peasantry he used an almost biblical language: the peasants received the land they needed for their work, and no one would be allowed to exploit them or to become rich at the expense of their efforts. ${ }^{46}$ In the same way, God had told Moses that he would provide manna for his people; however, if stored, it would have perished, so no accumulation was allowed, and everyone would receive according to their own needs. ${ }^{47}$

For many Italian communists, the Soviet Union and Italy - even more than France and Italy - constituted two opposed worlds, a Manichean division between good and evil. ${ }^{48}$ Despite news of the show trials, of inhuman treatment of dissidents and the 
Nazi-Soviet pact of 1939, which provoked a painful separation between many communists in the Western world and the Soviet Union, such a powerful myth often lingered on. Defining himself in 1942 as an ex-communist, Italian writer and exile Ignazio Silone used a religious metaphor to explain that he and others like him would carry the stigmata of communism forever in secret, so potent had been the infatuation and so crushing the disillusionment. ${ }^{49}$ Koestler, by this point an ex-communist too, explained: 'the Soviet myth - as distinct from Soviet reality - acts on its victims both on the rational and the irrational level. The two are, of course, so intimately tangled up in experience that it is difficult to reconstruct the various stages of becoming a mythaddict. $^{, 50}$

The 'God that failed' in the immediate pre-war years survived for many in the Cold War years, refuelled by the anti-fascist resistance in countries like France, Greece and Italy, where the willingness to continue to embrace communism was also a result of the rejection of western society and its values. ${ }^{51}$ At that point, the experience of local communist parties perhaps counted for more than the promise previously represented by the Soviet Union. Despite the failure of a short-lived collaboration with the PCd'I between 1948 and 1950 and again in 1954, shortly before his death Miglioli wrote a 'spiritual testament' in which he recalled that the Italian war of liberation of 1943-1945 and the democratic constitution of 1948 had been possible only in alliance with the socialists and the communists. ${ }^{52}$

Between Paris and Brussels: The 1920s

For geographical, historical, economic and cultural reasons, France was the preferred European country for Italian exiles. According to the 1931 census, Italian emigrants numbered 808,000 , representing the most numerous of the foreign communities in 
France. Of this number, Italian exiles numbered around 76,000 people during the interwar years. ${ }^{53}$ Italian refugees produced a higher number of newspapers in France than any other national group. The Paris police prefecture estimated some fourteen newspapers (including two fascist ones) in 1929, while the Jewish communities had seven, the Hungarians two and the Poles four. ${ }^{54}$ The Italian socialist-led Anti-Fascist Concentration counted, according to the Italian embassy to Paris, some 10,000 members nationally. ${ }^{55}$ Their importance in the transnational anti-fascist movement was recognised by the French left. The Committee for the Defence of the Victims of Fascism Comité de défense des victimes du fascisme, for example, was especially active after the establishment of Mussolini's Special Tribunal in 1927 in defending Italian refugees and their right of asylum in France. ${ }^{56}$ The French Communist Party (Parti communiste français; PCF) in particular sided with Italian exiles from the start. In November 1926, as the regime's 'Fascist laws' and internal repression forced many to leave Italy, the General Confederation of Labour (Confédération Générale du Travail; CGT) - the communist-dominated trade union - and the PCF organised a rally in Paris in support of Italian exiles, who were persecuted abroad by the regime just as they had been within Italy. Their fight was not seen as separate from that of French workers because both were preparing for social conflict. Repression by both Mussolini and the French government, so it was believed, was aimed at frustrating the attempt by immigrant workers, 'and particularly the Italians, so numerous and active, to side with the French workers in the coming battles'.57

Miglioli's networks in France included both Catholic and communist organisations, both French and Italian. More than had been the case when he was in Italy, at the heart of his message was a Marxist interpretation of fascism. For example, in May 1927 he gave a talk to the Christian Democratic organisation Young Republic (Jeune République) in Lyon, where he associated the dangers of fascism with those of 
imperialism. Fascism was not just an Italian phenomenon but rather originated in international capitalism. ${ }^{58}$ Comintern leaders appeared to find him very useful. From the start he had made clear to the Anti-Fascist Concentration that he supported a policy of unity with anyone who wanted to fight fascism. ${ }^{59}$ At the end of 1927 he was preparing a series of talks in Germany, having first established links with both German pro-Soviet groups and the Christian trade unions. ${ }^{60}$ Since he did not officially belong to the Communist Party but nevertheless took part in communist initiatives against fascism, he was generally seen as a fellow traveller of the Third International. Yet, precisely because he operated at its margins, he was at the same time considered by the Italian authorities to be one of the most dangerous anti-fascist propagandists. ${ }^{61}$ The fact that he did not hide his Catholicism, and indeed publicly declared it, often provoking negative rumours and disapproval among the audiences he was addressing, did not preoccupy Comintern leaders, who on the contrary thought that because of this Miglioli could contribute even more effectively to the communist cause. ${ }^{62}$

In 1928, after being expelled by the French government as a communist and one of the most dangerous Italian exiles, Miglioli moved to Brussels. A spy who shared a flat with Miglioli in Brussels and followed his work closely reported that although he was involved in Catholic societies and presented himself as a Catholic, he was actually in the service of the communists. This was allegedly the task Moscow had assigned him, since no communist would have been able to infiltrate the Catholic world. ${ }^{63}$ According to another spy, among the reasons for Miglioli's expulsion from France was his strategy of extending the anti-fascist struggle to include colonial territories, among them Tunisia and Morocco, as well as involving prominent Arab rebels in France. ${ }^{64}$ As a refugee in Brussels, Miglioli had to confront a hard knock for Catholic anti-fascists: the Lateran Pacts signed by Cardinal Gasparri and by Mussolini on 11 February 1929. The Concordat suggested to many that the Church's closeness to the 
regime was perhaps not only opportunistic but might also be due to ideological convergence, a speculation that weakened the efforts of the Christian democratic movements and Christian trade unionism worldwide. ${ }^{65}$ In May 1929 the Argentineanbased socialist newspaper L'Italia del popolo published a long interview with Miglioli on the Lateran Pacts, translated from Monde, a newspaper edited by the French communist, Henri Barbusse. ${ }^{66}$ Miglioli argued that Pius XI, unlike two of his predecessors - Leo XIII and Benedict XV - was the Pope of both Catholic and nonCatholic landowners. After the First World War fascists threatened and attacked proletarian priests and lay Catholic leaders who were close to the peasants while the Pope remained silent. The PPI came under the control of conservative Catholics who expelled the Christian democrats, some of whom, starting with the party's leader Luigi Sturzo, had to leave Italy. In the 1920s, while Christian democrats were accused of bolshevism, many in the Italian Popular Party increasingly viewed fascism sympathetically - a fact that was instrumental in the establishment of the dictatorship. The Lateran pacts only represented, according to Miglioli, the 'last part of the agreement'. Nothing new, he claimed, was advanced by the Concordat: issues of religious marriage and teaching were traditional Church demands, and in order to obtain them the Pope had showed a gradual but continuous submission to the needs of Mussolini's regime. Anti-fascist Catholics, he concluded, whether abroad, in confino or in prison, received the news with indifference; it did not constitute an obstacle to the continuity of their faith any more than the Russian Revolution had affected the beliefs of Russian Christians. The crisis of the Church was therefore not a crisis in Christian consciousness. ${ }^{67}$ The same distinction was later made by Sturzo, who also wrote critically about the Lateran Treaty from his American exile, even though he found fascism and communism equally irreconcilable with the Catholic religion ${ }^{68}$. 
Sympathy for Catholic anti-fascists came at that point from socialists and communists alike. In 1931 a socialist pamphlet written in Italian was sent clandestinely to addresses in Italy, taking advantage of a moment of conflict between Church and fascism over control of youth education in Italy. It distinguished the 'Machiavellian' Vatican from the Catholic masses the regime had victimised from the start, as well as from those Catholics who had chosen to fight for the freedom of their country and were sharing the same fate as all other anti-fascists. ${ }^{69}$ A year later, the clandestine PCd'I called on all anti-fascists to unite, addressing a pamphlet to Catholic working women to try to convince them that religion should not become a divisive factor among the oppressed. $^{70}$

Berlin: 1929-1933

In the summer of 1929 Miglioli moved from Brussels to Berlin. ${ }^{71}$ His interest in the German capital had been alive for some time, but his ignorance of the language had so far dissuaded him from relocating there, until, according to a fascist spy, he had decided to learn it. Given the difficulties facing the left in France, a world congress of the League Against Imperialism, an international anti-colonial organisation founded in Brussels in 1927, was transferred in 1929 from Paris to Frankfurt. A speech by Miglioli brought attention to the dangers of Italian imperialism, in particular towards Yugoslavia. Other speakers, including Barbusse and the Albanian exile Fan Noli, described fascism as the most dangerous of all forms of imperialism. Miglioli also attacked the Vatican for its betrayal of the 'real Catholic Church' through its ambition to create a new form of clerical-fascist imperialism. The most effective response to that plan, he believed, was to support a peasant mass movement, in Germany in particular. ${ }^{72}$ 
Miglioli's role also became important in the activities of the German League for the Rights of Man, which held an anti-fascist conference in Berlin on 9 and 10 March 1929. Among the orators were Fan Noli, Barbusse and the Hungarian socialist aristocrat, Count Mihály Károlyi. ${ }^{73}$ The League became increasingly concerned with the rise of fascism in Germany. At a public rally in November 1929 its leaders warned that the menace of fascism might spread to Germany in the near future, fostered as it was by close links with the industrial elites. According to Miglioli, the most immediate problem was that of Austrian fascism, which, if successful, might act as a beacon for the rest of Europe. If European anti-fascists did not unite in time, Austria and Germany were likely to be its next victims. ${ }^{74}$

In the same year, Berlin also hosted the first International Anti-Fascist Congress. Here too, fascism was recognised as not merely an Italian phenomenon, but one that also potentially involved all rural and urban working classes worldwide. Among the Christian speakers was Vitus Heller, organiser of the Bavarian Catholic peasants, who provided an interpretation of the origins of fascism in Austria. Anyone coming from Italy after 1922, he argued, could understand the main issue at stake: 'while in Italy fascism had, with its violence, united Catholic and socialist workers, in Austria their separation persisted, because of a huge mistake by the socialists, followed by another huge mistake by the Christian organizations' ${ }^{75}$ The French communist paper L'Humanité reported that Barbusse opened the event with greetings to the Soviet Union, 'the only State without fascism, the one that has realised the social revolution'. It was, he continued, the 'state of the workers and the peasants' and an 'example for all the oppressed of the world'. According to Károlyi, the fight against fascism meant a fight against Mussolini's imperialism and ultimately a fight for world peace. ${ }^{76}$ The next day another article on the congress emphasised in particular the "precise and vigorous speech' by Miglioli and his analysis of the development of Italian fascism. ${ }^{77}$ 
A thorough report on the meeting was provided in a pamphlet published by the press services of the Secours Rouge International, which had no ideological scruples in introducing Miglioli as one of the presiding members of the congress and the leader of the Italian Catholic peasant party. The pamphlet presented his description of the events in Italy that led to the dictatorship and his regret that the Church, which might have defended the Catholic victims of the regime, had instead concluded a pact with Mussolini. In Miglioli's analysis of the peasant question, fascism was defined as the most brutal form of the dictatorship of bankers and large landowners, characterised by the destruction of peasant organisations and of any agrarian reform that had thus far been obtained. ${ }^{78}$

While in Berlin Miglioli also worked as the Italian delegate for the League against Imperialism and Colonial Oppression. At a meeting organised by the German communist Willi Münzenberg in August 1931, Miglioli drew attention to the ruthless destruction of the Libyan resistance by the Italian army and to the fact that the League of Nations had failed to act, making it necessary to call for direct revolutionary action. In order to prepare for this, he continued, the League against Imperialism and Colonial Oppression had to liaise with the Muslim world. Münzenberg asked Miglioli to prepare a dossier on Italian colonial policy in Libya, including the extermination of the Arab population, mass deportations and widespread executions. ${ }^{79}$ Miglioli helped to publicise in the German anti-fascist press the desperate conditions of the Arab populations subjected to colonial rule. He was sent numerous Arab newspapers from Paris and Geneva, which he then passed on for translation. ${ }^{80}$ At a further meeting in October 1931, a special commission was set up to examine in depth the colonial situation, with a sub-commission established to study conditions in Italian North Africa. ${ }^{81}$

The immediate task, however, was the struggle against fascism in Germany. At a meeting in Berlin on 4-5 April 1931, a leading German anti-fascist group, the 
Kampfbund, defined Italian fascism as the final means used by the bourgeoisie to prevent the radicalisation of the masses and 'the transition of the economic crisis into a political crisis'; the bourgeoisie, it was concluded, was 'the bearer of this dictatorship'. In the same way in Germany the National Socialists and the Social Democrats, standing 'in the first rank in the front against the Soviet Union', were 'tools of the bourgeoisie' ${ }^{82}$ Miglioli was by contrast less sectarian and sought to maintain contacts with anti-fascists of all shades. In particular, he had begun to develop relations with the Catholic German Centre Party (Deutsche Zentrumspartei) . His hope was that the Centre Party might decide to oppose Hitler's National Socialists in order to avoid the series of mistakes committed in Italy by the PPI. To the great annoyance of the OVRA agents tasked with monitoring Miglioli, German Catholics appeared to forget about Miglioli’s links with Moscow. ${ }^{83}$ Police informers reported that Miglioli was also able to liaise with Catholic groups in Paris that sought to create a White International, such as the International Movement Towards Christian Communism (Mouvement International vers le Communisme Chretien) led by Quakers. ${ }^{84}$ Anti-fascism became a prominent issue in German left-wing discussions in the early 1930s, with numerous meetings held in Berlin focusing on the interpretation of fascism as an international phenomenon. ${ }^{85}$ The influence of Münzenberg and of Miglioli in particular was noted by Italian police informers in Berlin, who were always irritated that Miglioli, even after the Concordat, continued to be able to present himself as a Catholic trade unionist somehow tolerated by the Vatican. ${ }^{86}$ Miglioli's continued influence on priests who worked among the poor in Italy was valued by Münzenberg and Barbusse, according to the informers, because they thought his anti-fascist activity might be helpful with the lower clergy in Austria too. ${ }^{87}$ Some German Christian democrats were also sympathetic to Miglioli and assisted him every time the German police created difficulties about renewing his permit to stay in the country. He obtained several short-term renewals until, in October 1931, he was 
told he could have a further permit only until January 1932. In a life that was spent mostly across borders, he was distressed at the idea of having to pack up his belongings once again and move to live elsewhere. By summer 1931 he had become used to life in Berlin, where he had many friends and acquaintances. Moreover, he believed that the current German political situation was of critical significance, representing possibly a revolutionary situation that might spread to the rest of Europe. ${ }^{88}$ At the same time, he continued to attend church and to stay in touch with local Catholic organisations, a paradox that led some fascist spies to wonder whether he should be considered a double agent - for Russia and for the Vatican. ${ }^{89}$

Not long before leaving Berlin in 1933 Miglioli penned a short book, published in Italian in Brussels and addressed to Italian peasants. As the communist leader Ruggero Grieco - exiled in Paris, a member of Peasant International, and one of those closest to Miglioli, with whom he later worked on land reforms in post-war Italy wrote in the foreword to the book, Miglioli's defining characteristic was his 'peasant mentality', which carried with it religious convictions. Nevertheless, he added, Miglioli also believed that the world the poor had to struggle for was an earthly one, not simply the promise of an afterlife. For this reason, although he remained Catholic, Miglioli's message to the Italian peasantry was 'to do as in Russia'.${ }^{90}$ In his book Miglioli did not disguise his emotional attachment to 'his' peasants, whose economic circumstances had worsened during the dictatorship in Italy. He sought to explain to them his own experience abroad and the results of his studies of the peasant condition in other countries he had visited, under both authoritarian and democratic regimes. This was a book he could not have written in Italy: it represents fully the experience of exile with all its struggles and difficulties, but it is also one soaked in pro-Soviet propaganda.

Paris Again: The 1930s 
The escape from Berlin in 1933 brought to Paris thousands of German refugees, mostly Jews, communists, socialists and anti-Nazi intellectuals. The capital of anti-fascism moved west once again. ${ }^{91}$ In Paris, Barbusse created a Committee Against War and Fascism which organised the third International Anti-Fascist Congress, with Miglioli as the representative for the peasant section. Life for exiles was easier than it had been in France in the late 1920s because the country was now bordered by both Fascist Italy and Nazi Germany. A widespread anti-fascist sentiment developed, which led to the election of the Popular Front government three years later - an outcome recently described as 'an anti-fascist moment' in twentieth-century French history. ${ }^{92}$ In this new climate, as Miglioli recalled later in his memoirs, political emigration - including by Italians - was 'no longer barely tolerated but was now given adequate consideration'. 93

Two years later the Italian invasion of Abyssinia became the core of an international conference against war and fascism held in Paris on 23 and 24 November 1935, in which French left-wing ex-combatants also participated. The representatives of Italian anti-fascism - Egidio Gennari for the PCd'I, Carlo Rosselli for Justice and Freedom (Giustizia e Libertà, the liberal-socialist movement founded in Paris in 1929), and Miglioli himself - agreed on the role of Italian anti-fascist organisations abroad in doing all they could 'to incite the Italian population from its state of depression and prepare it for the revolution'. ${ }^{94}$ By the following year that very depression seemed instead to have spread among Italian exiles. According to one informer, following Mussolini's declaration of the empire in Ethiopia, an atmosphere of doom pervaded a party held by the Italian Association for Assistance and Popular Culture, a Paris-based exiles' cultural society, which Miglioli and Cocchi attended. ${ }^{95}$

Despite the changed public political climate, in 1935 Miglioli was included by the French security authorities on their 'list of suspects'. They had not forgotten that 
he had been expelled from France in 1928. Although he had been permitted to reside in France again in 1933 on the basis of three-month renewable permits, the French interior ministry worried about the perceived communist nature of his initiatives, and especially his frequent journeys to Moscow and the publications that followed. One book in particular, Le Village soviétique, was defined as 'an apology for the Soviet regime'. In September 1931 a trip to Spain, where a left-oriented republic had been proclaimed in April, and where Miglioli's book had been published in translation, was also noted, as was his participation in a number of European anti-fascist congresses. ${ }^{96}$ His French publications were kept under surveillance, as well as his contacts with the Soviet Union. While it was recognised that he had never declared that he was a communist and that his relationship with Moscow was mainly conducted through the International Agrarian Institute, he was suspected of being an agent of the Third International. ${ }^{97}$ His friendship with well-known anarchist exiles, such as the Italians Camillo Berneri and Fernando De Rosa - author of an attempt at the life of prince Umberto II of Savoy in 1929 and later killed in the Spanish Civil War in 1936 - was also observed. ${ }^{98}$

1937 was probably the most critical year for transnational anti-fascism. In May, Berneri, who was also a member of the Paris exile community, was assassinated by Stalinists in Spain. ${ }^{99}$ In June, Paris exiles and founders of Justice and Freedom Carlo and Nello Rosselli were murdered by OVRA agents at Bagnoles-de-l'Orne. In Moscow the show trials against Trotskyists had begun in January. Socialists and communists in France agreed in July on a new action pact, while the PCd'I in particular moved to include Catholics too, accepting that the division between the Catholic and non-Catholic masses had been responsible for the recent catastrophes in Italian history. ${ }^{100}$ Italian women who had emigrated to France published a pamphlet addressed to Catholic women in Italy in which they explained that their own anti-fascism was based on the Bible's precepts 'do not kill' and 'do not steal', and on Christ's principle to love one's 
brothers - all of which had been violated by Mussolini both in Ethiopia and in Spain. ${ }^{101}$ In March, Cocchi had founded the above-mentioned Union Populaire Italienne, whose very title betrayed its Catholic origins - a fact that Miglioli could not avoid pointing out in his own account of the interwar years. ${ }^{102}$ The Union was able to attract members beyond the Communist party, including many anti-fascists who did not belong to any party, as well as Catholics who had been urged by Cocchi to oppose the Italian regime as pagan and anti-religious. ${ }^{103}$ The Union supported the interests of Italian emigrants and encouraged the unity of all anti-fascists, while affirming very strongly the bond between them and the French people. No other Italian organisation abroad reached such a high number of members, probably around 40,000 in the whole of France. Its newspaper sold around 20,000 copies a day and counted some 4,000 subscriptions. ${ }^{104}$ As the possibility of war loomed larger over Europe, and the first doubts slowly began to insinuate themselves into the minds of many pro-Soviet exiles, feelings of gratitude to France began to emerge publicly and increasingly in the exiles' literature. One slogan of the Union Populaire was 'accept war and defend peace': anti-fascism, the defence of democracy and Franco-philia implied the acceptance of a potential conflict, as demonstrated by the civil war in Spain. However, Italian exiles believed that in theory there should be no contradiction between peace and anti-fascism and supported the Popular Front's motto: pain, paix, liberté. Pietro Nenni, one of the most distinguished leaders of the Italian Socialist Party and exiled to France, explained in the Union's newspaper the proletariat's rejection of war, rooted in the experience of 1914, and the need to turn war instead into revolution. Here the Soviet Union still served as an example of how to save peace while defeating fascism. ${ }^{105}$ But by the beginning of 1938 Italian exiles began to find hope in a possible conflict between France and Italy, which might provide them with the opportunity to fight for France and to end the dictatorship in their own country. The Union was the political arena in which battalions of emigrant 
volunteers would have been recruited. ${ }^{106}$ By December 1938 the Union was indeed defined by the Italian fascist police as an instrument in French hands. Cocchi did not fail to mention its 50,000 members who were supposedly ready to volunteer to fight with the French army. ${ }^{107}$

\section{The Final Crisis: Towards War and Beyond}

In 1938, worried about the future of Spain and of democracy in France, communist leaders such as Di Vittorio, Cocchi and Grieco appeared unwilling to find refuge in the Soviet Union for fear of 'being executed by Stalin'. ${ }^{108}$ Worried about the purges, Münzenberg also refused to go to Moscow and in October 1940 was assassinated by

Soviet agents in France. ${ }^{109}$ Koestler continued to believe that the Soviet Union remained the last hope in a 'decomposing planet' until the signing of the Nazi-Soviet pact in August $1939 .{ }^{110}$ An enquiry by the French ministry of defence in December 1939 was finally undertaken in order to verify whether Miglioli was a Soviet agent. ${ }^{111}$ Like the OVRA, the French authorities too thought he might be acting as a double agent paid at the same time by both Moscow and Rome. It is likely that the French security services began to worry about his role following the Nazi-Soviet pact and the outbreak of war. $^{112}$

The Nazi-Soviet pact threw the European communist world into a crisis of identity even more profound than the problem of coming to terms with the show trials. ${ }^{113}$ One victim of the crisis was the Union Populaire Italienne, even though it had been created under PCd'I leader Palmiro Togliatti's encouragement and was supposed to be in line with Comintern, and even though it included among its leaders communists residing in France, such as Grieco, Di Vittorio, Longo Montagnana and Cocchi. ${ }^{114}$ Numerous members, including Cocchi, declared open opposition to Moscow's 
policy. ${ }^{115}$ Fascist secret police reported that Cocchi was consequently expelled by the PCd'I, and that many others moved from the Italian Communist to the Socialist Party. ${ }^{116}$ By the end of December 1939 the directorate of the Union asked that at a local level its members formally take up a position against the Nazi-Soviet pact. ${ }^{117}$

France's involvement in the war and the coming threat from Nazi Germany encouraged the Union Populaire to rally to the country that had hosted more than 800,000 Italians and given them 'fraternity, liberty, bread'. The prospect of a French military collapse now seemed to represent the end of Europe, of civilisation and human progress. The Union saw it as the duty of Italian residents in France to contribute unreservedly to the achievement of victory by volunteering to fight, by labouring sideby-side with French workers and by participating - men, women and children - in civil resistance and passive defence. It was now remembered that Italy, twenty-five years before, had fought in the Great War on the French side. ${ }^{118}$ Fearing Italy's entry into the war on Hitler's side, a Union newspaper declared in February 1940 that 'for an Italian a war against France was unconceivable'. There was no attempt to deny the Union's continued criticism of French capitalism, but it was maintained that it had always distinguished between British and French imperialism, which 'allows the working class movements to live', and fascist and Nazi imperialism, which 'destroy the workers' movement with iron and fire'. Hitlerism had become the principal enemy of the proletariat. ${ }^{119}$ In March a condemnation of the Soviet Union appeared in the newspaper for the first time. ${ }^{120}$

When the German army entered Paris in June, all hopes for peace annihilated, many exiles destroyed all their political material and documents and sought to escape; others, however, decided to stay. Among them was Miglioli: tired at last of the continuous flight from country to country, he decided to remain in Paris, 'my place 
of work and of sorrow'. In a letter to French priest Abé Renaud, he wrote in December 1940:

Through these 40 years of life and struggles, I could maintain alive, thanks to God's grace, a Faith, I practiced it and hopefully I served it. I lived and worked most of the time among opponents' milieus, and I certainly committed many mistakes. But Don Bosco’s protection, in which I have been educated since I was seven years old and which I invoke every day, with the assistance of my Mother, who I venerate like a Saint, has never abandoned me. Now I live in poverty and with the only help of my family, seeking to still be useful to the cause which I have chosen in my youth. ${ }^{121}$

He later recalled in his 1945 memoir that, after he was arrested by the Germans and was being kept captive at the political prison of La Santé, he had been pondering in his cell about the writings he found on the walls:

Among so much brutality, so much truth! While unleashing vice, the dramas of so many souls! The human being reveals himself, but also the faults of the society, which are more to blame than human nature - so much so, that from the words of the curse against it, there often appears the beginning of a spiritual rebirth. With atonement, there is redemption, and the human rises towards comfort and hope. Even the name of God was witness to both miseries and virtues on those walls, both cursed and loved, never forgotten. ${ }^{122}$

\section{Conclusion}


The Italian communist resistance fighter Antonio Giolitti, while in a French hospital in February 1945, found himself reading Ernest Renan's Life of Jesus (1863) and reflecting on how Jesus had conceived God as a Father, and his kingdom as belonging to every human's heart. His conclusion was that religion, like communism, had no homeland. ${ }^{123}$ By examining the relationship between Catholics and communists through the activities of the principal leader of Italian anti-fascist Catholic exile, this article has proposed an interpretation of politics and society between the wars by seeking to recapture the rich diversity of ideological positions between the political poles of communism and fascism. In order to understand both national and international developments in the anti-fascist movement, both 'individual and network-based activism', as Constance Bantman and David Berry have recently put it, need to be considered. Cross-border interactions can help in 'retracing intellectual, militant and ideological transfers' within and between political movements, highlighting their 'hybrid character', 'ideological and militant borrowings' and 'processes of adaptation'. ${ }^{124}$

Just as in 1919 Miglioli had predicted (wrongly, as it turned out) that the Italian Socialist Party would achieve power in Italy, with the PPI as a party of the extreme left, so during his exile (and unlike Sturzo) he thought of a 'White International' not as a force of mediation between socialists and communists but as a force on their left wing in alliance in fact with the Third International. ${ }^{125}$ Indeed, Miglioli and other Catholics played a significant role in transnational anti-fascist initiatives in the 1930s. This is why the division between Catholics and communists simplifies the more complex political culture that characterised parts of Italy and Europe in the first half of the twentieth century. The White Leagues and the development of their anti-fascism outside Italy's borders provide an interpretation of communism from a theological perspective. Theirs was a religion brought into politics, not a 'political 
religion'. Though the idea of political religion has proved to be one of the most popular concepts in historiography of the last two decades, one of its essential limitations has been the neglect of 'true' religion, and of its relevance to political radicalism. ${ }^{126}$

Claudia Baldoli, School of History, Classics and Archaeology, Newcastle University, Newcastle upon Tyne NE1 7RU (UK); claudia.baldoli@ncl.ac.uk

${ }^{1}$ I wish to thank the British School at Rome for granting a Balsdon Fellowship in 2012 that allowed me to complete the research for this project. Throughout the article, all translations from Italian and from French are by the author.

${ }^{2}$ On Catholic labour history see Patrick Pasture, Histoire du syndicalisme chrétien international: La difficile recherche d'une troisième voie (Paris: L'Harmattan, 1999); Paul Misner, Catholic Labor Movements in Europe: Social Thought and Action, 19141965 (Washington DC: The Catholic University of America Press, 2015); Lex Heerma van Voss, Pasture and Jan de Maeyer, eds., Between Cross and Class: Comparative Histories of Christian Labour in Europe, 1840-2000 (Bern: Peter Lang, 2005); Denis Maugenest, Le mouvement social catholique en France au XX $X^{e}$ siecle (Paris: Cerf, 1990); Christian Sorrel, ed., L'engagement social des croyants: Lignes de force, expériences européennes, itinéraires alsaciens (Strasbourg: ERCAL, 2004). On Catholic Communism see Daniela Saresella, Cattolici a sinistra. Dal modernismo ai giorni nostri (Rome and Bari: Laterza, 2011); Daniel Arasa, Católicos del bando rojo (Barcelona: Styria, 2009).

${ }^{3}$ Among the many works on Sturzo, see Giorgio Vecchio, Luigi Sturzo. Il prete che portò i cattolici alla politica (Milan: Centro Ambrosiano, 1997); the most recent contribution on Murri is the first issue of the journal Modernism, devoted to Murri from Christian Democracy to Fascism, 1, 1 (2015). 
${ }^{4}$ See, among recent examples: Vincent Viaene, 'International History, Religious

History, Catholic History: Perspectives for Cross-Fertilization (1830-1914)', European History Quarterly, 38, 4 (2008), 578-607; special issue of The Journal of Modern History, 82, 2 (2010), on 'The Persistence of Religion in Modern Europe'.

${ }^{5}$ Sandro Mezzadra, 'Confini, migrazioni, cittadinanza', in Silvia Salvatici, ed., Confini. Costruzioni, attraversamenti, rappresentazioni (Soveria Mannelli: Rubbettino, 2005), 105; 'Confini. Introduzione', Snodi. Pubblici e privati nella storia contemporanea, 14 (2014), 7-8.

${ }^{6}$ Benedict Anderson, Under Three Flags: Anarchism and the anti-Colonial Imagination (London: Verso, 2007; 1st edn 2005), 1.

${ }^{7}$ Among works on the activity of the White Leagues in the Po Valley, see especially Franco Leonori et al., Leghe bianche e leghe rosse. L'esperienza unitaria di Guido Miglioli (Rome: Editori Riuniti, 1972); John Foot, “"White Bolsheviks?” The Catholic Left and the Socialists in Italy, 1919-1920', Historical Journal, 40, 2 (1997), 415-433. ${ }^{8}$ Antonio Gramsci, Quaderni del carcere, ed. Valentino Gerratana, vol. 2 (Turin: Einaudi, 2001), 1199; Gramsci, L'Ordine Nuovo 1919-1920, eds. Gerratana and Antonio Santucci (Turin: Einaudi, 1987), 285-286.

${ }^{9}$ Carlo Bellò, L'Azione: 1905-1922 (Rome: Cinque Lune, 1967), ix; xxvi.

${ }^{10}$ Bellò, La Provincia, 3 Nov. 1973; Ivanoe Bonomi, Leonida Bissolati e il movimento socialista in Italia (Milan: Cogliati, 1929), 23-24.

${ }^{11}$ See for example Camillo Prampolini, Come avverrà il socialismo e altri scritti (Venice: Marsilio, 1981; 1st edn 1894); Rossano Pisano, ed., Il paradiso socialista (Milan: Franco Angeli, 1986). On religious socialism in the southern Po Valley see Marco Fincardi, C'era una volta il mondo nuovo. La metafora sovietica nello sviluppo emiliano (Rome: Carocci, 2007), 41-42. On the rival activity of the Catholic and 
socialist leagues in the Po Valley see Guido Crainz, Padania. Il mondo dei braccianti dall'Ottocento alla fuga dalle campagne (Rome: Donzelli, 1994), 98-100.

${ }^{12}$ Stefano Bissolati, Esposizione di una coscienza, ed. Alberto Gottarelli (Milan: Giuffré, 1997; 1st edn 1864); Arturo Frizzi, Vita e opere di un ciarlatano, ed. Andreina Bergonzoni (Milan: Silvana, 1979; 1st edn 1902); Illemo Camelli, Dal socialismo al sacerdozio (Cremona: Unione Tip. Ed. Cremonese, 1911).

${ }^{13}$ Éric Vial, L'Union populaire italienne, 1937-1940. Une organisation de masse du parti communiste italien en exil (Rome: École Française de Rome, 2007).

${ }^{14}$ Romano Cocchi and Enrico Tulli, "Scandali” nella Vandea clericale (Milan: Società Editrice Avanti!, 1923), 35-36.

${ }^{15}$ Saresella, Cattolici a sinistra, 28-31. On Ferrari in France and Belgium and on his encounters with Sturzo in exile, see Casellario Politico Centrale (thereafter CPC), b. 2017, f. 15097, Archivio Centrale dello Stato, Rome (thereafter ACS); on Donati, CPC, b. 1841 , f. $86823 / 1-2$, ACS.

${ }^{16}$ La Stampa, 10 Feb. 1924, published in Pietro Scoppola, La Chiesa e il fascismo. Documenti e interpretazioni (Rome-Bari: Laterza, 1976), 89-96.

17 'I lavoratori delle organizzazioni bianche sono anch'essi per l'unità sindacale', Unità, 11 Dec. 1924.

${ }^{18}$ Misner, Catholic Labor Movements, 56-57.

${ }^{19}$ Guido Miglioli, Con Roma e con Mosca (Milan: Garzanti, 1945).

${ }^{20}$ On the similar case of German exiles in France see Jean-Michel Palmier, Weimar in Exile: The anti-Fascist Emigration in Europe and America (London: Verso, 2006), 184218; on the case of French exiles in the United States from 1940, Emmanuelle Loyer, Paris à New York. Intellectuels et artistes français en exil, 1940-1947 (Paris: Grasset, 2005). 
${ }^{21}$ Katerina Clark makes a similar point with regards to German exiles in Moscow:

Moscow: the Fourth Rome. Stalinism, Cosmopolitanism, and the Evolution of Soviet Culture, 1931-1941 (Cambridge MA: Harvard University Press, 2011), 31-32.

${ }^{22}$ Biographical note by the Italian ministry of interior, 1928, CPC 3274, f. 1, ACS.

${ }^{23}$ Stéfanie Prezioso, Itinerario di un 'figlio del 1914'. Fernando Schiavetti dalla trincea all'antifascismo (Manduria: Pietro Lacaita, 2004), 313; Carmela Maltone, Exil et Indentité. Les antifascistes italiens dans le Sud-Ouest, 1924-1940 (Pessac: Presses Universitaires de Bordeaux, 2006), 63.

${ }^{24}$ Friedrich Reck, Diary of a Man in Despair (New York: New York Review of Books, 2013; 1st German edn 1947), 34.

${ }^{25}$ Ralph Schor, Écrir en exil. Les écrivains étranger en France, 1919-1939 (Paris: CNRS, 2013), 96; 112; 129.

${ }^{26}$ Prezioso, Itinerario di un 'figlio del 1914', 323.

${ }^{27}$ Éric Vial, 'I fasci in Francia', in Emilio Franzina and Matteo Sanfilippo, eds., Il fascismo e gli emigrati (Rome and Bari: Laterza, 2003), 30; Mimmo Franzinelli, I tentacoli dell'OVRA. Agenti, collaboratori e vittime della polizia fascista (Turin: Bollati Boringhieri, 1999), 128-129.

${ }^{28}$ Andrea Ricciardi, Leo Valiani. Gli anni della formazione. Tra socialismo, comunismo e rivoluzione democratica (Milan: Franco Angeli, 2007), 175.

${ }^{29}$ Giulia Canali, L'antifascismo italiano e la guerra civile spagnola (San Cesario di Lecce: Manni, 2004), 7-9; Stéfanie Prezioso, “"Aujourd'hui en Espagne, demain en Italie": L'exil antifasciste italien et la pris d'armes révolutionnaire', Vingtième Siècle. Revue d'histoire, 93 (1), 2007, 80. The Spanish Civil War divided Catholics too: see Pasture, Histoire du syndicalisme chrétien international, 186-188. 
${ }^{30}$ See CPC, Romano Cocchi, b. 1385, f. 1097/1-2, ACS; Vial, L'Union populaire italienne, 181-182.

${ }^{31}$ Guido Miglioli, Una storia e un'idea (Turin: Accame, 1926).

${ }^{32}$ Miglioli, Le Village soviétique (Paris: Librairie du Travail, 1927), 178.

${ }^{33}$ Emilio Gentile, Contro Cesare. Cristianesimo e totalitarismo nell'epoca dei fascismi (Milan: Feltrinelli, 2010), 127.

${ }^{34}$ Cocchi, Lettera ai contadini bianchi d'Italia (Milan: Edizioni del consiglio internazionale dei contadini, 1925), 7-8.

${ }^{35}$ Orlando Figes and Boris Kolonitskii, Interpreting the Russian Revolution: the Language and Symbols of 1917 (New Haven e London: Yale University Press, 1999), 146. See also Nina Tumarkin, Lenin Lives! The Lenin Cult in Soviet Russia (Cambridge Mass: Harvard University Press, 1983) and, on the Soviet myth among Italian antifascists, Marcello Flores, L'immagine dell'Urss. L'occidente e la Russia di Stalin (1917-1956) (Milan: Il Saggiatore, 1990).

${ }^{36}$ Miglioli, Le Village soviétique, 61.

${ }^{37}$ Fincardi, C'era una volta il mondo nuovo, 42-43.

${ }^{38}$ Arthur Koestler, Arrow in the Blue (London: Readers Union, 1954), 196.

39 Theo de Wit, 'Politics without Dénouement, Faith without Guarantee: A Critical Appraisal of the Politics of Religion of the Left and the Right', in Péter Losonczi and Aakash Singh, eds., From Political Theory to Political Theology: Religious Challenges and the Prospects of Democracy (London: Continuum, 2010), 127.

${ }^{40}$ Paolo Spriano, Storia del Partito Comunista Italiano, vol. 2, Da Bordiga a Gramsci, part 2 (Turin: Einaudi - L’Unità, 1967), 493-494.

${ }^{41}$ Miglioli, Con Roma e con Mosca, 54.

${ }^{42}$ Ibid., 55. 
${ }^{43}$ Miglioli, Le Village soviétique, 5.

${ }^{44}$ Miglioli, La Collectivisation des campagnes soviétiques (Paris: Rieder, 1934), 15-16.

${ }^{45}$ Ibid., 35.

${ }^{46}$ Ibid., 37.

${ }^{47}$ Exodus (Old Testament), 16, 15-35, La Sacra Bibbia (Rome: CEI, 2014), 101.

${ }^{48}$ Patrizia Gabrielli, Col freddo nel cuore. Uomini e donne nell'emigrazione antifascista (Rome: Donzelli, 2004), 79.

${ }^{49}$ Jean-Marc Négrignat, Avoir été communiste. Les autobiographies de Koestler, Löbl et Silone (Paris: Éditions des archives contemporaines, 2008), 19; 20-21.

${ }^{50}$ Koestler, Arrow in the Blue, 194.

${ }^{51}$ Koestler, L. Fischer, A. Gide, I. Silone, S. Spender and R. Wright, The God that Failed (New York: Harper and Brothers, 1949). For the Italian case, see Joanne Lee, 'Political Utopia or Potemkin Village? Italian Travellers to the Soviet Union in the Early Cold War', Modern Italy, 20, 4 (2015), 379-393. See also Spriano, I comunisti europei e Stalin (Turin: Einaudi, 1983).

${ }^{52}$ Miglioli, 'Testamento spirituale', published in Leonori, No Guerra ma terra! Guido Miglioli: una vita per i contadini (Milan-Rome: CEI, 1969), 274. On Miglioli’s dilemma between Christian Democracy and Communist Party in post-war Italy see Claudia Baldoli, 'Guido Miglioli: il percorso di un cattolico nell'Italia del dopoguerra', in Mario Isnenghi, ed., Le rotte dell'io. Itinerari individuali e collettivi nella storia d'Italia (Naples: Scriptaweb, 2008), 127-153.

${ }^{53}$ Franzinelli, I tentacoli dell'OVRA, 125; Vial, 'I Fasci in Francia', 27; Schor, Écrir en exil, 11. See also Pierre Milza, ed., Les Italiens en France de 1914 à 1940 (Rome: EFR, 1986). 
54،Presse étrangère', 19 Jan. 1929, B/A 1714, 2100-5, Archives de la Préfecture de la Police, Paris (thereafter APP).

${ }^{55}$ Maltone, Exil et identité, 67.

56 'Comité de défense des victimes du fascisme', leaflet by Henri Barbusse, president of the committee, 23 Jun. 1927, B/A 23.160, APP.

57 'Italie', 'Comité Prolétarien Antifasciste', report by the prefecture of Paris on the relationship between French and Italian anti-fascists, 30 Oct. 1926, and French communist poster of 4 Nov. 1926, B/A 2387, 1.00.443/204, APP.

${ }^{58}$ Italian consul at Lyon to the Italian foreign office, the Italian embassy to Paris and the Italian head of police, 5 May 1927, CPC 3274, f. 1, ACS.

${ }^{59}$ Two Italian police informers' notes from Paris, 15 Nov. 1927, ibid.

${ }^{60}$ Note by the Italian Political police to the ministry of interior, 15 Dec. 1927 , ibid.

${ }^{61}$ Italian police informer's note from Paris, 15 Nov. 1927, ibid.

${ }^{62}$ Biographical note by the Italian ministry of interior, 1928 , ibid.

${ }^{63}$ Political police report from Brussels, 10 Oct. 1928, CPC 3274, f. 2, ACS.

${ }^{64}$ Political police reports from Paris, 3 Aug. and 10 Oct. 1928, ibid.

${ }^{65}$ Pasture, Histoire du syndicalisme chrétien international, 124-125. For a recent historiographical overview on the relationship between the Church and fascism see Lucia Ceci, 'La Chiesa e il fascismo. Nuovi paradigmi e nuove fonti', Studi Storici, 55 (January-March 2014), 123-137. For a nuanced assessment of the relationship between the Vatican and fascist totalitarianism, see John Pollard, The Vatican and Italian Fascism: A Study in Conflict, 1929-1932 (Cambridge: Cambridge University Press, 1985), and The Papacy in the Age of Totalitarianism, 1914-1958 (Oxford: Oxford University Press, 2014), especially chapters 4-7.

${ }^{66}$ Federica Bertagna, La stampa italiana in Argentina (Rome: Donzelli, 2009), 136. 
${ }^{67}$ Interview to Miglioli by Pierre Hubermont, translation published as 'Fascismo e Vaticano: Quello che dice 1'On. Guido Miglioli', L'Italia del popolo, 9 May 1929. ${ }^{68}$ Sturzo, The Vatican's Position in Europe (New York: Council on Foreign Relations, 1944), 7.

69 'Il fascismo e la Chiesa', Lotta antifascista, 3, Jun.-Jul. 1931, Ministero dell'Interno (thereafter MI), DGPS, F1 (1926-43), b. 71, ACS.

${ }^{70}$ La religione non deve impedire l'unione di tutti gli sfruttati (PCd'I, 1932), MI, DGPS, F1 (1926-43), b. 76, ACS.

${ }^{71}$ Italian foreign office to ministry of interior, 5 Aug. 1929, CPC 3274, f. 2, ACS.

72 Political police report from Berlin, 17 Aug. 1929, ibid.

${ }^{73}$ Italian embassy to Berlin to foreign office, 13 May 1929, ibid.

${ }^{74}$ Italian embassy to Berlin to the ministry of interior, 24 Nov. 1929, ibid..

${ }^{75} \mathrm{Ibid}$; a similar interpretation was shared by Miglioli, although he was aware that, due to long-term divisions over the issue of anti-clericalism, Catholic and socialist trade unions came to an agreement against fascism only in 1922, when it was too late (Miglioli, Con Roma e con Mosca, 80).

76 ‘300 délégués acclament la lutte mondiale contre le fascisme', L'Humanité, 10 Mar. 1929.

77 'Dans un meeting réunissant dix mille prolétaires les délégués parlent...', L'Humanité, 11 Mar. 1929.

${ }^{78}$ Service de Presse du Secours Rouge International, n. 11, 19 Mar. 1929, special issue on the International Anti-Fascist Congress of Berlin, F/7/13248, Archives Nationales, Pierrefitte-sur-Seine, Paris (thereafter AN).

${ }^{79}$ On the Italian colonization of Libya see Nicola Labanca, La guerra italiana per la Libia, 1911-1931 (Bologna: Il Mulino, 2012). 
${ }^{80}$ Informer's report from Berlin to the ministry of interior, 23 Aug. 1931, CPC 3274, f. 3, ACS.

${ }^{81}$ Informer's report from Berlin to the ministry of interior and the foreign office, 26 Oct. 1931, ibid.

82 'Kampfbund gegen den Faschismus', conference reports published on Alarm, n. 7, Apr. 1931, Rep. 77 Ministerium des Innern, 1, Sektion 31, Titel 4043 Politische Polizei, 362-363, Geheimes Staatsarchiv Preussicher Kulturbesitz, Berlin.

${ }^{83}$ Informer's report from Berlin to the ministry of interior, 23 Oct. 1930, CPC 3274, f. 3, ACS.

${ }^{84}$ Italian embassy to Paris to the Italian foreign ministry, 2 Feb. 1930, MI, DGPS, DPP, b. 102, Cat. K-28, f. 14 ('Internazionale bianca'), ACS.

${ }^{85}$ As reported by a number of confidential reports by fascist spies who followed Miglioli's activities (CPC 3274, f. 3, ACS).

${ }^{86}$ Informer's report from Berlin to the ministry of interior, 26 Mar. 1931, CPC 3274, f. 3, ACS.

${ }^{87}$ Informer's report from Berlin to the ministry of Interior, 24 Mar. 1931, ibid.

${ }^{88}$ Three informer's reports from Berlin to the ministry of interior, 1 and 8 Jul. and 8 Aug. 1931, ibid.

${ }^{89}$ Italian embassy to Berlin to the foreign office and the ministry of interior, 17 Oct. 1931, ibid.

${ }^{90}$ Ruggero Grieco, foreword to Guido Miglioli, La tua marcia. Lettera al contadino italiano (Brussels: Edizioni di Cultura Sociale, 1932), 4-5.

${ }^{91}$ Anson Rabinbach, 'Paris, Capital of anti-Fascism', in Warren Breckman, Peter E. Gordon, A. Dirk Moses and Samuel Moyn, eds., The Modernist Imagination: Intellectual History and Critical Theory (New York: Berghahn, 2009), 183-209. 
${ }^{92}$ Vincent Chambarlhac and Thierry Hohl, eds., 1934-1936. Un moment antifasciste (Paris: La Ville Brûle, 2014) ; Gilles Vergnon, L'antifascisme en France: de Mussolini à Le Pen (Rennes: Presses Universitaires de Rennes, 2009), 43-99.

${ }^{93}$ Miglioli, Con Roma e con Mosca, 147. Milza, Le Fascisme italien et la presse française, 1920-1940 (Bruxelles: Editions Complexe, 1987), 208.

${ }^{94}$ Italian embassy to Paris to the foreign office and ministry of interior, 26 Nov. 1935, CPC 3274, f 4, ACS. In his memoir Miglioli later emphasised that the origins of his anti-colonialism were to be found in his opposition to the Italian war in Libya in 19111912, and that his very first speech as he entered Parliament in 1913 had been against Liberal Italy's occupation of Tripoli.

${ }^{95}$ Informer's note from Paris to the Italian ministry of interior, 23 May 1936, CPC 3274, f 4, ACS.

${ }^{96}$ Miglioli, La aldea soviética (el problema agrario en Rusia) (Madrid: Ulises, 1931). ${ }^{97}$ Some of his travels appeared to be funded by the Agrarian Institute. See for example informer's report to the Italian ministry of interior, 26 Jul. 1934, CPC 1385, f. 1097 (2), ACS.

${ }^{98}$ French ministry of interior, report on 'Miglioli Guido, anti-fascist', 4 Jul. 1935, F/7/14746, AN.

${ }^{99}$ For a biography of Berneri, see Carlo De Maria, Camillo Berneri: Tra anarchismo e liberalismo (Milan: Franco Angeli, 2004).

${ }^{100}$ Romano Canosa, I servizi segreti del duce. I persecutori e le vittime (Milan: Mondadori, 2000), 351.

${ }^{101}$ Sorelle nostre, spose e madri cattoliche che siete in Italia, ascoltate la voce delle donne italiane emigrate in Francia, May 1937, MI, DGPS, F1 (1926-1943), b. 52, ACS. 102 Miglioli, Con Roma e con Mosca, 147. 
${ }^{103}$ Informer's report to the ministry of interior, 3 Sept. 1938, CPC 1385, f. 1097 (2), ACS. However, Sturzo continued to oppose such unity between Catholics and communists, as he also demonstrated with regards to the Spanish Civil War: despite his excellent connections with Spanish liberal Catholics who fought for the Republic, he believed that the Church should only be concerned with 'innocent victims on both sides' (Alfonso Botti, ed., Luigi Sturzo e gli amici spagnoli. Carteggi (1924-1951), Soveria Mannelli: Rubbettino, 2012, 7-8).

${ }^{104}$ Pietro Pinna, Migranti italiani tra fascismo e antifascismo. La scoperta della politica in due regioni francesi (Bologna: CLUEB, 2012), 127-132; Vial, L'Union populaire italienne, 204.

${ }^{105}$ Pietro Nenni in La Voce degli italiani, 28 Jul. 1937.

${ }^{106}$ Canosa, I servizi segreti del duce, 352.

${ }^{107}$ Political police report from Paris to the Italian ministry of interior, 21 Dec. 1938, MI, DGPS, DPP, b. 24, f. 3, ACS.

${ }^{108}$ Political police report from Lyon to the Italian ministry of interior, 19 Apr. 1938, ibid.

${ }^{109}$ Schor, Écrir en exil, 206-208; Palmier, Weimar in Exile, 312-314.

${ }^{110}$ Gianni Sofri, Introduction to the Italian edition of Koestler's Scum of the Earth: Schiuma della terra (Bologna: Il Mulino, 2005), xiii.

111 'Dossier concernant Miglioli Guido 1929-1940’, 22 Dec. 1939, Terre 7 NN/3151, f. 39.001, Service Historique de la Defénce, Château de Vincennes, Paris (thereafter SHD). Even if he was not an agent, Miglioli was close to the Comintern as he still appeared as part of Czech delegate Bohumir Smeral's network in Paris in a report of Jan. 1938: 'Rapport du camarade Smeral a propos du travail a Paris en 1937', Communisme. Les Kominterinens. I. Dossier Willi Münzenberg, 38-39, 1994, 69. 
${ }^{112}$ Reports of 12 Oct. and 16 Jun. 1933, and of 16 Oct. 1939, Terre 7 NN/3151, f. 39.001, SHD.

${ }^{113}$ See Bernhard H. Bayerlein with Wolfgang Leonhard, Der Verräter, Stalin, Bist Du! Vom Ende der linken Solidarität. Sowjetunion, Komintern und kommunistische Parteien im Zweiten Weltkrieg 1939-1941 (Berlin: Aufbau-Verlag, 2008).

${ }^{114}$ Note by the Prefecture of Paris, 1 Jun. 1939, F/7/14748, AN; Italian Embassy to Paris to the Italian ministry of interior, 24 Apr. 1939, CPC 1385, f. 1097 (1), ACS. ${ }^{115}$ Note by the Prefect of Paris, 7 Nov. 1939, ibid.

${ }^{116}$ Informers' reports to the Italian ministry of interior, 8 Nov. and 16 Dec. 1939, CPC 1385, f. 1097 (2), ACS.

${ }^{117}$ Special police officer Julliard, Lyon to the prefect of Rhône, 23 Dec. 1939, F/7/14748, AN.

118 'Un appel de l'Union populaire italienne aux 850.000 Italiens de France', Epoque, 14 May 1940.

${ }^{119}$ L'Unione, 18-25 Feb. 1940.

120 'Plus que jamais contre la collusion communiste-hitlérienne', L'Unione, 24-31 Mar. 1940. See also Cocchi, Amitié franco-italienne (Paris: Comité d'amitié franco-italienne, 1939), which includes letters of support to Cocchi and the Union by leaders of the PCF Maurice Thorez, of the Christian Democratic party 'La Jeune République' Philippe Serre, and of the Socialist party Jean Zyromski (27-28).

${ }^{121}$ Letter dated early Dec. 1940 and published in Carlo Bellò and Amos Zanibelli, eds., Guido Miglioli. Documenti inediti: 1940-1945 (Rome: Cinque Lune, 1980), 37-38.

${ }^{122}$ Con Roma e con Mosca, 227.

${ }^{123}$ Antonio Giolitti, Di guerra e di pace. Diario partigiano (1944-1945), eds. Rosa Giolitti and Mariuccia Salvati (Rome: Donzelli, 2015), 73 
${ }^{124}$ Constance Bantman and David Berry, eds., New Perspectives on Anarchism, Labour and Syndicalism: The Individual, the National and the Transnational (Cambridge: Cambridge Scholars, 2010), 10.

125 ‘Partito Popolare Italiano’, L’Azione, 8 Mar. 1919.

${ }^{126}$ See, among many works on the subject, Emilio Gentile, Politics as Religion (Princeton: Princeton University Press, 2006). The debate generated by the concept has even led to the foundation of a dedicated academic journal, Totalitarian Movements and Political Religions published by Taylor \& Francis. 